\title{
METHODS FOR DIAGNOSING THE EFFECTIVENESS OF THE ENTERPRISE'S FINANCIAL STRATEGY IN THE STRATEGY CONTROLLING SYSTEM
}

\author{
Maryna Reta', Elena Druhova ${ }^{2}$ \\ National Technical University "Kharkiv Polytechnic Institute", Ukraine \\ Oksana Lisnichuk ${ }^{3}$ \\ Ukraine State Fiscal Service University, Ukraine
}

\begin{abstract}
The purpose of the article is to describe how the controlling system is implemented and controlling tools are applied at enterprises in Ukraine. The article contains selected results of the survey research conducted by the authors at logistics enterprises in Ukraine. The obtained data were used to verify the hypotheses and to evaluate the controlling system implementation at the pharmaceutical companies in Ukraine. Methodology. To substantiate the essence of management accounting tools, the authors used the method of grouping of management accounting tools, affecting the achievement of its goals. The results of the empirical study show that almost half of the surveyed logistics companies use controlling systems in business practice. These are primarily large and medium logistics enterprises regarding employment scope and annual sales revenue. The companies applying the controlling system, as well as the business entities without it actually use operational (traditional) controlling tools, e.g. traditional cost accounting systems complemented by the selected strategic method of controlling. Conclusion. The proposed classification of management accounting tools permits to organize the terminological apparatus of the management accounting system in general and at enterprises in particular.
\end{abstract}

Key words: strategic controlling, strategic management, controlling tools, solutions in controlling, strategic method of controlling, controlling system, strategic scorecard, unclear plurals, level, system of indexes, finance.

JEL Classification: R14, D18, P2, B40, G39, M40

\section{Introduction}

Modern globalization, constantly growing market competition, consumers' changing tastes, permanent technology development and ever-increasing requirements for quality and workability of products and services make the enterprise management focus simultaneously upon three different vectors: to improve own competition position in the market, to minimize risks of adverse events affecting enterprise's activities etc., to create conditions for sustainable development. To meet these requirements, the enterprise's managers should implement different management tools, directed both upon effective management of internal processes and forecasting of external impact to achieve the desired effect and to ensure balanced enterprise sustainable development. One of the modern management tools, widely expanded in the second half of the XX century, is controlling, aimed at creating the proper information support needed to make reasonable management decisions. Controlling is a modern management concept, which allows a quick response to changes in the environment and aimed at creating appropriate adaptation measures. At the same time, the need for conditions for the long-term sustainable development of the enterprise requires the development and implementation of the strategic controlling. The enterprise development in long perspectives is largely determined by the quality and probability of information support for strategic management. So it seems reasonable to assert that the key information includes target values of key indicators defined by the mission, vision, and strategic behaviour of enterprises. Issues of strategic controlling implementation in business

\footnotetext{
Corresponding author:

${ }^{1}$ Department of Economic Analysis and Accounting, National Technical University "Kharkiv Polytechnic Institute”.

E-mail:rinavmar@gmail.com

2 Department of Management of Foreign Economic Activity and Finance, National Technical University "Kharkiv Polytechnic Institute”.

E-mail: drugova.elena.sergeevna@gmail.com

${ }^{3}$ Department of Finance, Ukraine State Fiscal Service University.

E-mail: oksanaskvur81@gmail.com
} 
management have not been yet described enough. So the goal of this research is to ground scientific and practical approaches to building and implementation of strategic controlling, to determine strategic controlling tools, to analyse opportunities for their application at Ukrainian pharmaceutical enterprises.

\section{Theoretical specification of strategic controlling}

Controlling as a concept first was developed in the US, but the modern content of this category appeared in Germany. So, currently, the terms "management accounting", "managerial accounting" are used in the United Kingdom and the United States. In Ukraine, both terms are used but controlling as a system at the level of economic entities practically is hardly applied. Ukrainian scientists just begin to develop the controlling theory, to study its existence and applicability in the domestic economy. Aspects of controlling as the science are studied by such economists as J. Weber, A. Daite, E. Mayer, R. Mann, D. Khan, P. Horvat, M.S. Pushkar, L.O. Suharova, S.M. Petrenko, T.A. Lev, D.V. Gulin, O.L. Maksimenko, S.A. Smirnov, O.A. Tereshchenko, I.I. Tsigilik, and others.

The researches show that "controlling" concept is defined differently in modern literature (Table 1).
This is actually caused by that at every enterprise controlling is associated with different needs and functioning conditions leading to individualization of implementation and functioning of the controlling system, mechanism, and process.

So, in our opinion, controlling is a functionally separated direction of informative analysis at the company related to the information support function for the management decision-making of financial and economic, resource, operational, tactical, and strategic nature. Unlike other accounting and analytical systems providing information support for management processes, the strategic controlling system is aimed at revealing the main tendencies and events in the external and internal environment that may impact on the business, and allows to assess resource support for developed plans (Tokareva, 2008), revealing errors, factors, and problems, which impede the implementation of selected strategies, and developing measures for the adaptation of enterprise's strategies to changing environmental conditions, which in turn helps adopt perfect management decisions (Zhilina, Zagidullina, 2011).

The controlling system is an accounting and analytical system, implementing the synthesis of elements of accounting, control, planning, forecasting,

Table 1

Controlling definitions in the literature

\begin{tabular}{|c|c|}
\hline Author & Definition characteristic \\
\hline $\begin{array}{l}\text { Edward Nowak } \\
\text { (Edward Nowak, 2011) }\end{array}$ & $\begin{array}{l}\text { "Controlling is a company management system supporting managers in controlling the course of the business } \\
\text { processes taking place therein and coordinating various areas of activity from the point of view of the company } \\
\text { as a whole to achieve the assumed goals." }\end{array}$ \\
\hline $\begin{array}{l}\text { M. Sierpiriska } \\
\text { (M. Sierpiriska } \\
\text { and B. Niedbala, 2014) }\end{array}$ & $\begin{array}{l}\text { "Controlling may be treated not only as an integrated system of planning and control but also as a certain } \\
\text { philosophy of operation of an effective and flexible company, skilfully manoeuvring in the dynamic and } \\
\text { uncertain environment. Controlling understood in such a way is a tool for selection of the organisation's } \\
\text { development strategy, objectives and tasks, coordination and assistance in the performance of these tasks, } \\
\text { assessment of the success rate of the entity on the market, and growth in its market value [14]." }\end{array}$ \\
\hline $\begin{array}{l}\text { J. Weber } \\
(\text { J. Weber, 2001) }\end{array}$ & $\begin{array}{l}\text { "Controlling means a function inside the management system in such companies, whose executive system } \\
\text { (operation) is coordinated through plans. The purpose of controlling is to coordinate all management } \\
\text { subsystems. It has the same instruments and mechanisms at its disposal, which are used by the management } \\
\text { system. The purpose of controlling is to increase the effectiveness and efficiency of management and strengthen } \\
\text { adaptation to the changes taking place inside and outside the company." }\end{array}$ \\
\hline $\begin{array}{l}\text { Bokareva L.G. } \\
\text { (Bokareva, 2008) }\end{array}$ & $\begin{array}{l}\text { Interprets strategic controlling as a new form of management for the assessment of resources availability and } \\
\text { implementation of announced plans. Quality of development of long-term projects, their ability to achieve the } \\
\text { set goals is controlled by strategic controlling [6]. }\end{array}$ \\
\hline $\begin{array}{l}\text { Alekseyeva I.V. } \\
\text { (Alekseyeva, 2010) }\end{array}$ & $\begin{array}{l}\text { Defines the purpose of strategic controlling as evaluation of implemented strategic goals set by top-management } \\
\text { in terms of resources' availability, and rates "coefficient of resistance" of the environment (quality management, } \\
\text { corruption, institutional restrictions, and etc.), where these goals are implemented [7] }\end{array}$ \\
\hline $\begin{array}{l}\text { Mann R. } \\
\text { (Mann, 2012) }\end{array}$ & $\begin{array}{l}\text { "Controlling is a system of rules which prevents surprises and the red light on when danger appears to require } \\
\text { relevant measures in the management." }\end{array}$ \\
\hline $\begin{array}{l}\text { Refäuter, D. } \\
\text { (Refäuter, 1990) }\end{array}$ & $\begin{array}{l}\text { "Controlling is called subsystem of the management system, it helps to achieve business goals, it prevents from } \\
\text { surprises, and it draws attention to danger at the time. It is a specific form of work with information. The role of } \\
\text { controlling is not to manage but to help management by using information about real processes." }\end{array}$ \\
\hline $\begin{array}{l}\text { Gurčík, L., } \\
\text { (Gurčík, 2001) }\end{array}$ & $\begin{array}{l}\text { "Controlling is an integration tool of management that supports management decisions venture and managers. } \\
\text { The base controlling is very good information systems and management accounting. It enables effective } \\
\text { communications among organizational subsystems of the company." }\end{array}$ \\
\hline
\end{tabular}

Source: compiled by the authors according to the research results 
coordination, providing both operational and strategic management of goal achievement and enterprise's performance. The development of strategic thinking and strategic approaches to management resulted in changes in controlling concept - contributed to the development of its strategic aspect, aimed at forming abilities and development of adaptation strategies and enterprise's adjustment to changes in the environment, basing on the strategic planning and coordination system. With the enterprise's strategic controlling, a mechanism is created to quickly respond to innovations and changes of market environment, however, in our opinion, controlling implies not only a situational reaction but also provides tools for forecasting and developing preventive measures to minimize the risk of the external and internal environment. The strategic controlling system includes two levels of management:

- strategic level - the system of the enterprise's strategic accounting (assessment of the correctness of the decisions at different levels of management in terms of compliance with the general strategy of enterprise development);

- operational level - the system of the enterprise's management and financial accounting.

Some authors (Konsek, Ciechonska, 2017) suggest the controlling concept be considered in functional, instrumental, and institutional aspects to effectively harmonize directions of its development and functionally separate from other management subsystems. However, in spite of the management levels, in our opinion, the goal of strategic control is to reveal organizational, technical, and financial abilities to achieve strategic plans in terms of rapid changes in the external business environment, as well as to keep monitoring of the results of the implementation of strategic goals and objectives.

A corporate strategy defines prospects for enterprise development in general. It focuses upon implementing the enterprise's mission and is aimed at maximizing the owners' welfare. Typically, the enterprise functional strategies are formed by its main activities. The main strategies of this level include: marketing, production, financial, innovation, etc. However, it should be noted that in the formation of common strategic goals, their financial components should be considered first, as well as financial goals, which may adjust the process of forming the enterprise's general strategy. Financial strategic goals are formed based on the enterprise's general strategic goals, directly related to each other and play a leading role in the effectiveness of the enterprise's strategy implementation (Lisnichuk, 2012).

Ensuring the enterprise's sustainable development in the long perspective contributes to the implementation of effective mechanisms for assessing threats of the internal and external environment in order to minimize their impact on the strategy results. And therefore, it becomes relevant to develop and implement appropriate methodological approaches to the assessment of the effectiveness of the enterprise's implemented strategic goal that would have high reliability.

\section{Theoretical researches of strategic controlling tools}

Strategic controlling collects basic information for the preparation of a strategic plan and includes assessment of the stakeholders' expectations, and keeps monitoring indicators characterizing of the enterprise strategy implementation effectiveness. To perform these basic controlling functions in economic theory and practice, many tools have been developed. Controlling tools often coincide with the management accounting tools, which essence is its complexity, consistency, and coherence of individual components of the tools. Thanks to the synergy in mobilizing the company's potential, which enhances the ability of its counteraction to environment influence (Mazaraki, Fomina, 2016). At the same time, the strategic controlling system is aimed at coordinating all management subsystems, using all available tools and mechanisms inherent in the conventional management system. The purpose of controlling is to increase the management efficiency and to strengthen adaptation to changes inside and outside the company.

Management accounting tools are economic tools, which allow to methodically (technically) implement its procedures. A.A. Taran and R.M. Tsygan distinguish the following tools of management accounting:

- information and reporting tools implemented through permanent analysis of financial results, expenses of responsibility centres, adjustment of accounting information, support for the operative formation of internal management reporting on the enterprise's business activity;

- matrix-analytical tools (calculation of expenses for the product life cycle, of target costs, of investments, of cost and its deviation, cost analysis);

- tactical and operational tools (financial analysis of performance indicators, static and dynamic tools for investment evaluation, budgeting, functional and cost analysis, expenses accounting and costing, standardcosting, targeting-costing, $\mathrm{ABC}$-costing, Kaizencosting, direct costing, analysis of indirect costs, etc.); - strategic predictive tools (SWOT analysis, GAP analysis, balanced scorecard system (BSC), portfolio analysis (analysis of the activity distribution according to individual strategies for products and markets, etc.) (Taran, Tsygan, 2013).

A. Mazaraki and O. Fomina have another opinion (Mazaraki, Fomina, 2016), offering the classification of controlling tools by the following areas: management functions (accounting, analytical, control, organizational); management accounting (operational, strategic).

For example, strategic analytical tools may include: investment analysis, strategic analysis (including 
analysis of strategic partners: competitors, buyers, suppliers); analysis of own potential; quality analysis; strategic pricing (pricing at the product lifecycle stages), value chain analysis, cost factors, product life cycle, strengths and weaknesses (SWOT analysis), functional and cost analysis (FCA). Such strategic analytical tools as a balanced scorecard system and management reporting become independent. However, each of these tools is not focused upon solving the problem of quick and easy monitoring of the effectiveness of the enterprise's strategy implementation, which makes difficult generating relevant objective information through a strategic controlling system. Therefore, using the researchers' experience, we propose to improve the methodology of the diagnostics of the effectiveness of the enterprise's strategy implementation.

The variety of existing concepts and tools suggests that the issue of diagnostics in modern strategic management is considered quite deeply. However, methodological approaches that fully satisfy the needs of express diagnostics have not yet been proposed. In our opinion, the diagnostics of the effectiveness of the enterprise's strategy implementation in the strategic controlling system is a continuous process of complex identification of problems (deviations according to certain criteria) in the strategic plan of the enterprise development, aimed at optimization and adjustment of the enterprise's strategic development. That is, the diagnostics of the enterprise's strategy effectiveness conceptually should include two components: determination of the scope of evaluation and formation of a list of criterion indicators and based building indicators to assess the effectiveness of the enterprise's strategy implementation. According to the current definition, the purpose, objects, methods, and principles of diagnostics in the strategic enterprise management system are determined (Figure 1).

However, it should be noted that the financial indicators are considered to be indicators of enterprise

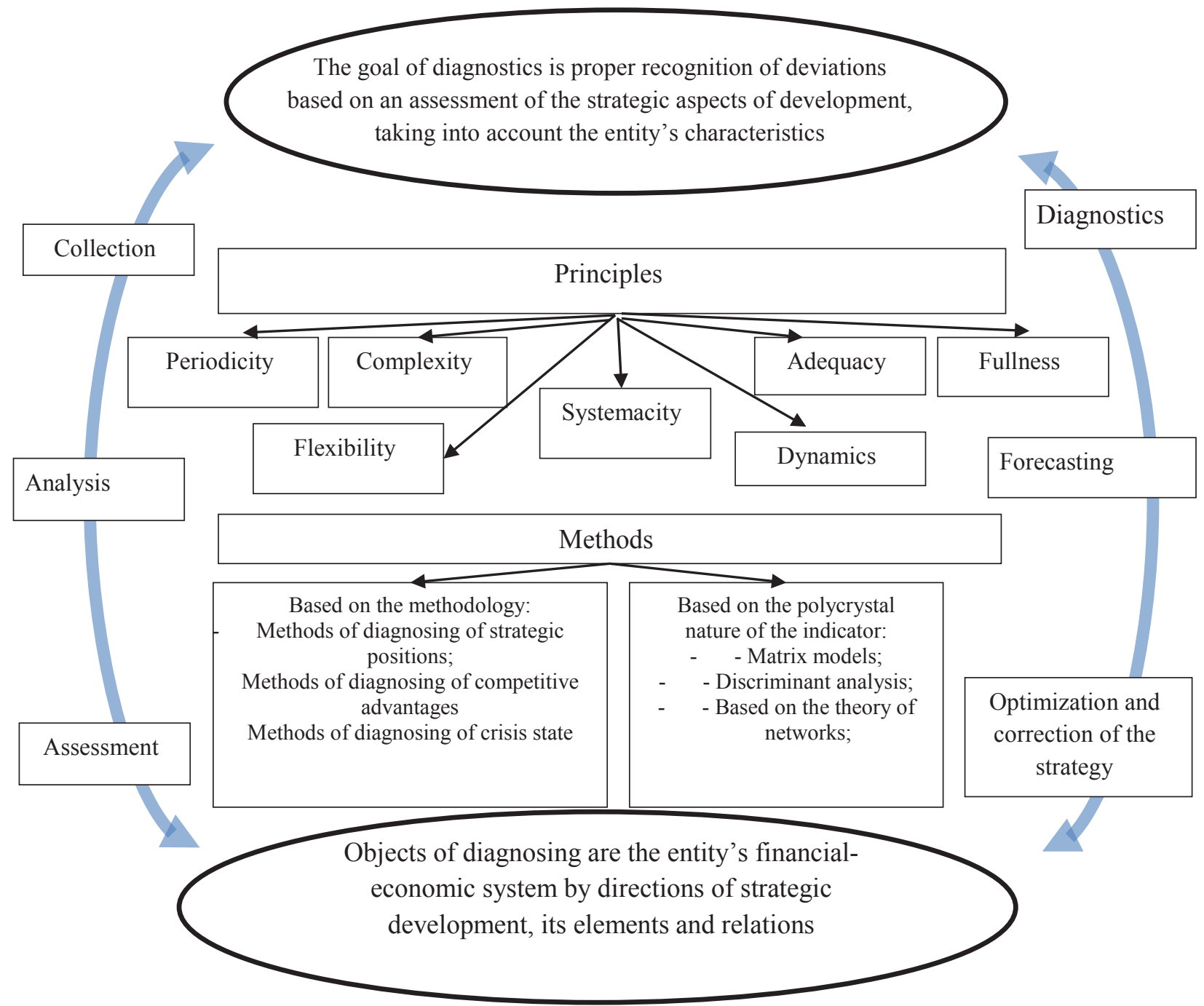

Figure 1. Diagnosing the implementation strategy effectiveness, as a part of the enterprise's strategic management Source: by the author (Reta, 2016) 
development and the effectiveness of its strategy implemented. The effective financial strategy of the enterprise ensures implementation of the enterprise functional strategies, and therefore, deterioration of the enterprise's financial indicators shows stable adverse trends in their development. Therefore, in our opinion, in the first place, the effectiveness of the enterprise's strategy implementation should be determined through its financial component.

The modern concept of sustainable development involves balanced development by four components finance, customers, internal business, and development. The development by these four components is consistent with the balanced scorecard concept, which came into common use at modern enterprises enabling them to determine their own indicators and to generate one within each of the four components considering characteristics and specifics of the enterprise. However, one tested in certain studies can be accepted as a basis (Table 2).

According to the balanced scorecard system, it is planned to group the system of indicative indicators into four directions. The implementation of this approach aims to form a set of indicators, which assess the enterprise's strategy effectiveness primarily based on publicly available data that can be obtained from public information sources. Following the hypothesis that the enterprise's strategic goal and tasks should generally be focused upon ensuring the enterprise's long-term sustainable development, we believe that the strategy implementation effectiveness will firstly be determined by achievement of the planned level of key indicators for each area of the enterprise's activity, which are collectively aimed at the enterprise's strategy implementation. In our opinion, the strategy implementation can be considered in two aspects global (creation of conditions for continuous growth of the enterprise and creation of additional cost) and local (possibility of implementation of separate components of the general strategy by separate directions). The result of the evaluation is to obtain an integral indicator, which allows evaluating not only the overall effectiveness of the strategies but also to obtain information for changes.

The choice of the method for evaluating the strategy implementation effectiveness depends on the accuracy of the assessments obtained, calculation complexity, intuitive understanding of the calculation algorithm, and other factors providing the convenience of the practical application of the method. So the plural fuzzy tool is believed in many cases to be simpler than probabilistic

Table 2

Strategic scorecard for the company

\begin{tabular}{|c|c|c|c|}
\hline Index & Strategic goals & $\begin{array}{c}\text { Strategic indicators } \\
\text { Effects of achievement of } \\
\text { objectives }\end{array}$ & $\begin{array}{c}\text { Strategic indicators } \\
\text { Factors of future success }\end{array}$ \\
\hline \multirow{3}{*}{$\begin{array}{l}\text { Financial perspective includes indicators } \\
\text { affecting the increase in the enterprise cost } \\
\text { and considered by the investor in making } \\
\text { decisions }\end{array}$} & Growth in sales level & Sales growth rate & $\begin{array}{l}\text { Sales growth as compared to } \\
\text { the plan }\end{array}$ \\
\hline & Reduction in operating costs & Cost level ratio & $\begin{array}{l}\text { Costs reduction as compared } \\
\text { to the plan }\end{array}$ \\
\hline & $\begin{array}{l}\text { Improvement in debt } \\
\text { collection }\end{array}$ & Receivable turnover ratio & Debt management program \\
\hline \multirow{3}{*}{$\begin{array}{l}\text { Customer perspective includes indicators } \\
\text { describing the value of products and } \\
\text { services for consumers, requirements and } \\
\text { meeting of the need for the enterprise's } \\
\text { products or services, consumer properties } \\
\text { of products, for which the consumer agrees } \\
\text { to pay }\end{array}$} & Increase in market shares & Market share & $\begin{array}{l}\text { Monitoring of the } \\
\text { construction market }\end{array}$ \\
\hline & Fast and excellent service & $\begin{array}{l}\text { Average time of order } \\
\text { execution }\end{array}$ & Customer satisfaction survey \\
\hline & Building of customer loyalty & $\begin{array}{l}\text { Number of new customers as } \\
\text { compared to regulars }\end{array}$ & Customer satisfaction survey \\
\hline \multirow{3}{*}{$\begin{array}{l}\text { Internal-business-processes perspective } \\
\text { includes indicators characterizing creation } \\
\text { of values necessary for consumers, namely: } \\
\text { organization of technological and business } \\
\text { processes of the enterprise }\end{array}$} & Branding & Expenditures on advertising & Brand recognition surveys \\
\hline & High product quality & Number of complaints & $\begin{array}{l}\text { Assessment of internal } \\
\text { quality control systems }\end{array}$ \\
\hline & $\begin{array}{l}\text { Optimization of order } \\
\text { execution time }\end{array}$ & Order execution time & Order processing study \\
\hline \multirow{3}{*}{$\begin{array}{l}\text { Learning and development perspective } \\
\text { includes indicators of modernization } \\
\text { and improvement of their know-how, } \\
\text { determination of ways to support the } \\
\text { necessary level of process productivity } \\
\text { and efficiency, indicators of increase of the } \\
\text { enterprise's human resources and personnel } \\
\text { management }\end{array}$} & $\begin{array}{l}\text { Systematic employee } \\
\text { qualification improvement }\end{array}$ & Employees productivity & $\begin{array}{l}\text { Expenditures on trainings as } \\
\text { compared to the plan }\end{array}$ \\
\hline & $\begin{array}{l}\text { Ensuring adequate level of } \\
\text { employee satisfaction }\end{array}$ & Employee productivity & Satisfaction survey \\
\hline & $\begin{array}{l}\text { Streamlining of information } \\
\text { systems }\end{array}$ & $\begin{array}{l}\text { Expenditures on information } \\
\text { systems }\end{array}$ & Access to IT technologies \\
\hline
\end{tabular}

Source: compiled by the authors according to the research (J. Konsek-Ciechońska, 2017; V.M. Porohnya, V.O. Losj, 2008) 
methods. Even researchers which affirm the affinity of the two approaches, indicate that the fuzzy set theory may be more accessible for practical use (Smolinska, 2011).

In order to structure the approach to assessing the effectiveness of the enterprise's strategy implementation, indicators $\mathrm{x} 1, \mathrm{x} 2, \ldots, \mathrm{xn}$ can be combined into groups that would characterize individual aspects of this complex concept. Accordingly, we should evaluate the weight of $\beta j$ of each of $m$ groups of the indicators. In addition, each $i$ indicator in $j$ group can be put in line with $p_{i j}$ assessment of its importance in recognizing the level of the enterprise's strategy effectiveness.

The weights of baseline $p_{i j}$ and groups $\beta j$ are determined using the Fishburn scale (Fishburn, 1981; Shvets \& Tsykalo, 2017). In accordance with the Fishburn principle, the indicators are ranked in order of decreasing weight, and their weightings after the ranking are calculated by the formula:

$$
p_{i j}=\frac{2 \cdot\left(n_{j}-i+1\right)}{n_{j} \cdot\left(n_{j}+1\right)}, \quad \beta_{j}=\frac{2 \cdot(m-j+1)}{m \cdot(m+1)}
$$

The Fishburn's Rule reflects that nothing is known about the importance of indicators and their groups except their hierarchy. Then the estimation (1) corresponds to the maximum entropy of the available informative uncertainty about the research object. A generalized indicator of the effectiveness of the enterprise's strategy $(\mathrm{g})$ is calculated by the formula:

$$
g=\sum_{j=1}^{m} \beta_{j}\left[\sum_{i=1}^{n_{j}} p_{i j} \cdot x_{i j}\right]
$$

where $\mathrm{j}$ is the index of the group of indicators, $j=1$, $m$; $i$ - the index of the indicator in the group, $i=1$, $n_{j} ; n_{j}$ - number of indicators in $j$ group; $\beta_{j}$ - the weight of $\mathrm{j}$ group; $p_{i j}$ - the weight of $\mathrm{i}$ indicator of $\mathrm{j}$ group.

Indicators used to diagnose the effectiveness of strategy implementation should meet the following requirements: indicators should be used, which have a sufficient impact on the final result of the enterprise's activity. Therefore, in order to construct the model, we selected 15 relative indicators that characterize the four most important aspects of the enterprise's activity in strategic development. The indicators are selected by the following provisions: - the indicator significance and influence on the enterprise's financial and economic state; indicator information value; - relative simplicity of calculation and availability of indicators (availability of information necessary for their calculation in public reporting).

The selected indicators characterize the dynamics of the enterprise's economic development (Table 3 ). The rank of the group and the rank of the indicator in the group are selected in an expert way using the appropriate methods.

Also, we note that all indicators are stimulants (i.e., the higher value of the individual indicator, the higher level of effectiveness of the enterprise's strategic development), which makes it avoid any additional transforming formulas.

\section{Results and discussion of researches on the strategic controlling at enterprises in Ukraine}

To approve the proposed methodology, we selected the pharmaceutical industry of Ukraine as one of the most dynamically developed branches of the economy. The pharmaceutical market in Ukraine remains the second largest in the CIS countries (after Russia). The sale structure in the market, as in previous years, consists mainly of finished pharmaceuticals ( $84 \%$ of total sales in 2017), medical products, cosmetics and dietary supplements (A. Chernorotov, 2018). One of the important tendencies in 2016-2017 is the change of the negative dynamics of the decline in sales in kind to positive, with the subsequent acceleration of growth. Thus, in 2017, drug sales in the retail segment amounted

Table 3

\begin{tabular}{|c|c|c|c|}
\hline Group of indicators & Group ranking & Group indicators & Group indicators ranking \\
\hline \multirow{7}{*}{ Finance } & \multirow{7}{*}{2} & Cover ratio $\left(\mathrm{X}_{11}\right)$ & 6 \\
\hline & & Quick ratio $\left(\mathrm{X}_{12}\right)$ & 5 \\
\hline & & Absolute liquidity ratio $\left(\mathrm{X}_{13}\right)$ & 4 \\
\hline & & Equity-assets ratio $\left(\mathrm{X}_{14}\right)$ & 3 \\
\hline & & Financial stability index $\left(\mathrm{X}_{15}\right)$ & 1 \\
\hline & & Coefficient of long-term financial independence $\left(\mathrm{X}_{16}\right)$ & 2 \\
\hline & & Manoeuvrability factor of equity $\left(\mathrm{X}_{17}\right)$ & 7 \\
\hline \multirow{2}{*}{ Customers } & \multirow{2}{*}{1} & Net change profit $\left(\mathrm{X}_{21}\right)$ & 2 \\
\hline & & Return on sales $\left(\mathrm{X}_{22}\right)$ & 1 \\
\hline \multirow{4}{*}{ Internal processes } & \multirow{4}{*}{4} & Return on assets $\left(\mathrm{X}_{31}\right)$ & 3 \\
\hline & & Fixed assets suitability $\left(\mathrm{X}_{32}\right)$ & 4 \\
\hline & & Return on equity $\left(\mathrm{X}_{33}\right)$ & 2 \\
\hline & & Profitability of assets $\left(\mathrm{X}_{34}\right)$ & 1 \\
\hline \multirow{2}{*}{ Personnel } & \multirow{2}{*}{3} & Productivity $\left(\mathrm{X}_{41}\right)$ & 1 \\
\hline & & Personnel cost-effectiveness $\left(\mathrm{X}_{42}\right)$ & 2 \\
\hline
\end{tabular}

Practical strategic scorecard to measure the strategy implementation effectiveness 
to about 61.2 billion UAH or 1.1 billion packages, that is, the growth in monetary terms was $20.8 \%$, in kind $6.5 \%$ (in $2016-19.8 \%$ and $5.6 \%$ respectively). The growth of drug sales significantly outpaced the growth rate of retail trade in the country (in $2017-8 \%$ ). This tendency persists in 2018 as well, according to the results of this March, drug sales in Ukraine increased by $26.6 \%$ in monetary terms and by $6 \%$ in kind. One of the key indicators of the market - the weighted average price of one package of domestic medicinal products - as for 2017 amounted to $31.4 \mathrm{UAH}(+14,7 \%$ compared to 2016), and imported medicines - 128,3 UAH (+8.8\%). In 2017 , there was an increase in the substitution impact on the price (growth of sales in kind and partial change in demand in the segment of more expensive drugs), while reducing the impact of the inflation component.

Local companies have strong positions in the retail sector. So, according to the analysis of work in 2017, the top 20 companies have 9 Ukrainian companies. There is also a gradual change in the ratio of domestic and imported medicines to the increase of domestic products, such growth was $10 \%$ in 2016 (Ukrainian pharmaceutical market tendencies, 2017). The share of Ukrainian manufacturers in the domestic pharmaceutical market in the monetary term continues to increase. By the end of 2017, this figure amounted to $43.3 \%$ (in $2016-43.0 \%$, in $2015-41.5 \%$ ).

The estimation of the effectiveness of the strategy implementation by the pharmaceutical enterprises of Ukraine is shown below. The research was conducted on four Ukrainian pharmaceutical companies: Farmak Public Joint Stock Company (Farmak PJSC), Darnitsa Pharmaceutical Firm Private Company (Darnitsa PC), Kyiv Vitamin Plant Private Company (KVP PC), Scientific and Production Centre "Borshchagovsky
Chemical and Pharmaceutical Plant” Public Joint Stock Company (Borschagovsky CPP PJSC).

The integral indicator for assessing the strategy implementation effectiveness was calculated by the formula (2). The calculation results are shown in Table 4.

According to the analysis, it can be noted that during the analysed period, implementation of strategic development at the investigated pharmaceutical companies tended to worsen, despite certain positive developments in general in this area.

In general, the studied enterprises are able to withstand internal and external threats; however, in order to increase the implementation efficiency, certain adjustments should be made to handle weaknesses and to create a comprehensive information base for timely monitoring of the global strategy implementation and functional strategy implementation. The offered indicator of estimation of the enterprise's strategy implementation efficiency allows rapid diagnostics based on indicators calculated on public data and expansion of the list of indicators depending on analytical needs of the enterprise management.

\section{Conclusions}

In conclusion, it should be noted that strategic controlling as a new form of management control allows determining expediency, efficiency, rationality of the business strategy, in order to achieve a balanced, sustainable, and long-term profitable financial and economic activity of the enterprise, which is adjusted depending on external economic conditions and competition level.

Summarizing the results of the research, it should be noted that permanent changes in the enterprise's

Table 4

Calculation of the integral indicator of the strategy implementation efficiency at pharmaceutical companies

\begin{tabular}{|l|c|c|c|c|c|c|c|c|}
\hline \multirow{2}{*}{ Group indicators } & \multicolumn{2}{|c|}{ Farmak PJC } & \multicolumn{2}{c|}{ KVP PC } & \multicolumn{2}{c|}{ Darnitsa PC } & \multicolumn{2}{c|}{ Borschagovsky CPP } \\
\cline { 2 - 9 } & 2016 & 2017 & 2016 & 2017 & 2016 & 2017 & 2016 & 2017 \\
\hline Cover ratio $\left(\mathrm{X}_{11}\right)$ & 0,031 & 0,038 & 0,048 & 0,058 & 0,062 & 0,138 & 0,054 & 0,054 \\
\hline Quick ratio $\left(\mathrm{X}_{12}\right)$ & 0,026 & 0,032 & 0,024 & 0,032 & 0,063 & 0,155 & 0,036 & 0,039 \\
\hline Absolute liquidity ratio $\left(\mathrm{X}_{13}\right)$ & 0,001 & 0,002 & 0,002 & 0,003 & 0,037 & 0,103 & 0,002 & 0,002 \\
\hline Equity-assets ratio $\left(\mathrm{X}_{14}\right)$ & 0,098 & 0,132 & 0,208 & 0,183 & 0,178 & 0,393 & 0,295 & 0,278 \\
\hline Financial stability index $\left(\mathrm{X}_{15}\right)$ & 0,113 & 0,171 & 0,267 & 0,199 & 0,246 & 0,285 & 0,333 & 0,328 \\
\hline $\begin{array}{l}\text { Coefficient of long-term financial } \\
\text { independence }\left(\mathrm{X}_{16}\right)\end{array}$ & 0,043 & 0,046 & 0,051 & 0,051 & 0,049 & 0,057 & 0,055 & 0,054 \\
\hline Manoeuvrability factor of equity $\left(\mathrm{X}_{17}\right)$ & 0,003 & 0,003 & 0,003 & 0,005 & 0,006 & 0,008 & 0,003 & 0,003 \\
\hline Net change profit $\left(\mathrm{X}_{21}\right)$ & 0,092 & 0,030 & $-0,022$ & 0,028 & $-0,015$ & 0,000 & 0,125 & $-0,044$ \\
\hline Return on sales $\left(\mathrm{X}_{22}\right)$ & 0,036 & 0,037 & 0,027 & 0,027 & 0,043 & 0,036 & 0,027 & 0,016 \\
\hline Return on assets $\left(\mathrm{X}_{31}\right)$ & 0,074 & 0,070 & 0,066 & 0,069 & 0,074 & 0,090 & 0,026 & 0,028 \\
\hline Fixed assets suitability $\left(\mathrm{X}_{32}\right)$ & 0,006 & 0,006 & 0,008 & 0,010 & 0,005 & 0,005 & 0,006 & 0,006 \\
\hline Return on equity $\left(\mathrm{X}_{33}\right)$ & 0,016 & 0,008 & 0,010 & 0,006 & 0,010 & 0,005 & 0,006 & 0,002 \\
\hline Profitability of assets $\left(\mathrm{X}_{34}\right)$ & 0,007 & 0,007 & 0,007 & 0,006 & 0,005 & 0,005 & 0,006 & 0,002 \\
\hline Productivity $\left(\mathrm{X}_{41}\right)$ & 1,090 & 0,910 & 1,578 & 1,222 & 1,761 & 1,431 & 1,586 & 1,423 \\
\hline Personnel cost-effectiveness $\left(\mathrm{X}_{42}\right)$ & 0,073 & 0,063 & 0,080 & 0,061 & 0,141 & 0,097 & 0,081 & 0,042 \\
\hline Integral indicators & 1,709 & 1,556 & 2,358 & 1,958 & 2,664 & 2,807 & 2,640 & 2,233 \\
\hline
\end{tabular}



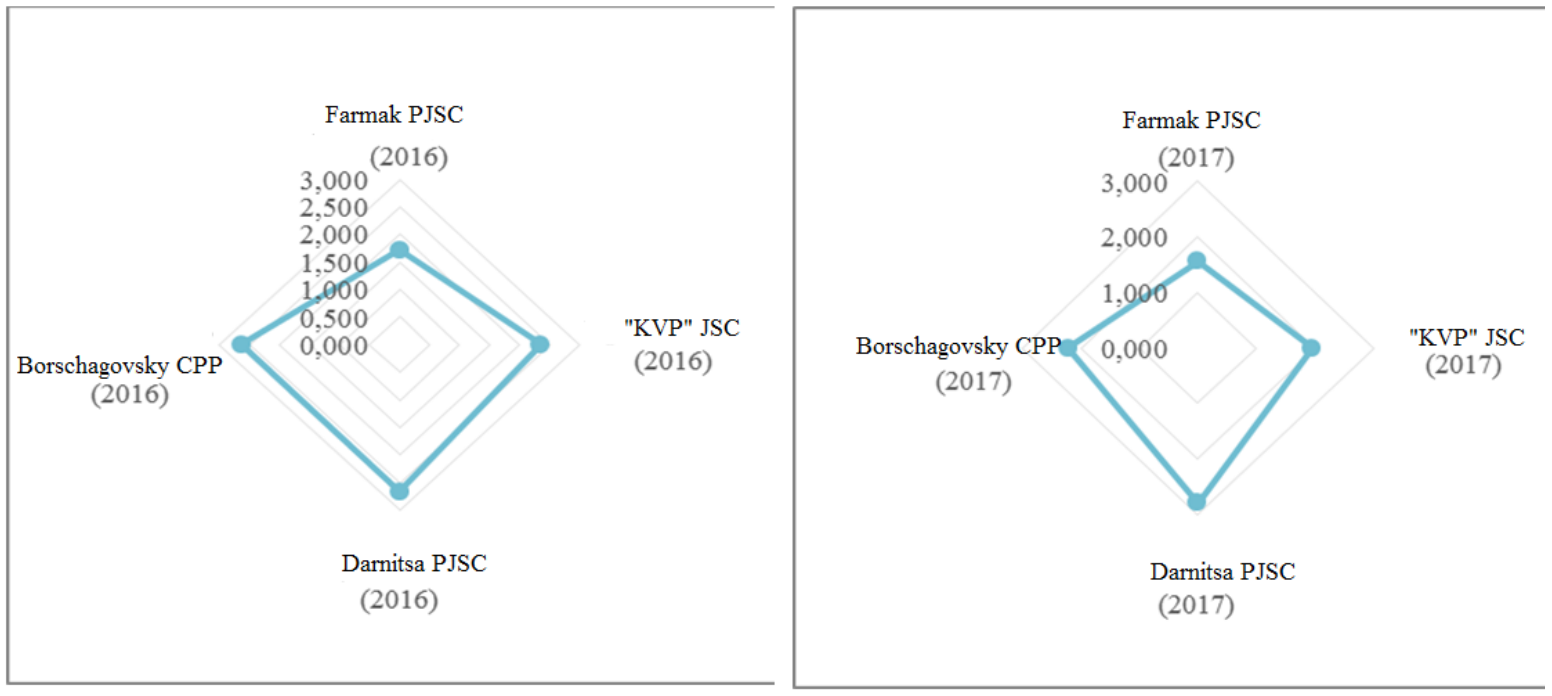

Figure 2. Results of the evaluation of the effectiveness of the enterprise's strategy implementation and comparison of the values obtained

activity and transformation of the main management functions necessitate controlling to be implemented, which the main purpose is to form rational information flows at the enterprise. Controlling can be described as a forward-looking system of informational, analytical, methodological, and instrumental support for implementing the management cycle in all areas of the enterprise's activities and processes. Controlling is a key management tool, required for implementing the strategy of the enterprise's sustainable development. The conducted researches indicate that the proposed integral indicator may increase the analytical capabilities of the diagnostics and provide a multilevel assessment of the enterprise's strategy effectiveness. The advantage of this indicator is the ability to obtain a resultant value that is defined as the weighted average by all selected indicators, on the one hand, and by all qualitative levels of these indicators, on the other.

Tools and methodological approaches to the formation of indicative values require further development to help the enterprise management determine its state and efficiency timely and at a minimum cost in order to regulate its activities and measures for a rapid response to changes.

\section{References:}

Adamenko A.A., Rybantseva M.S. (2012). Differentsiatsiya vzglyadov na sistemu kontrollinga i ee informatsionnoe napolnenie [Differentiation of opinions on the controlling system and its information content]. International Accounting. No. 11, pp. 54-62. (in Russian)

Alekseyeva I.V. (2010). Issledovanie sushchnosti i ekonomicheskoy prirody strategicheskogo audita [Investigation of the essence and economic nature of strategic audit]. Audit and financial analysis, No. 6, pp. 172-182. (in Russian) Bokareva L.G. (2008). Innovatsionnoe razvitie i zadachi finansovogo kontrolya [Innovative development and financial control tasks]. Finansy, No. 9.

Chernorotov A. Razvitie farmatsevticheskogo rynka Ukrainy [Development of the Ukrainian pharmaceutical market]. Retrieved from: http://www.credit-rating.ua/en/analytics/analytical-articles/14333/ (accessed on 15 February 2018) (in Russian)

Zhilina N.N., Zagidullina T.S. (2011). Zarubezhnye modeli kontrollinga i vozmozhnosti ikh primeneniya v Rossii [Foreign models of controlling and possibilities of their application in Russia]. International accounting. No. 36, p. 62-66. (in Russian)

Fishburn P. (1981). Theory of utility. Investigation of operations. Methodological fundamentals and mathematical methods. M.: Mir. Vol. 1, p. 448-480.

Gurčík L. (2001). Podnikatel'ská analýza a kontroling (Business analysis and controlling). Slovak University of Agriculture in Nitra.

Kholod Z.M., Zubrei I.V. Kontrolinh yak skladova stratehichnoho upravlinnia pidpryiemstvom (na prykladi pidpryiemstv polihrafichnoi promyslovosti) [Controlling as a component of strategic enterprise management (by examples of printing enterprises)]. Retrieved from: https://dspace.uzhnu.edu.ua (accessed on 21 January 2018) (in Ukrainian)

Konsek-Ciechońska J. (2017). Operational and strategic controlling tools in microenterprises - case study. Management Systems in Production Engineering. Volume 25, Issue 4, pp. 278-282. 
Mann R. (1989). Praxis strategisches Controlling mit Checklist und Arbeitsformuralen - von der strategischen Planung zur ganzheitlichen Unternehmensführung, Landsberg am Lech, 1989.

Mazarak, A., Fomina O. (2016). Tools for management accounting. Economic Annals-XXI. 159 (5-6), pp. $48-51$. Morgun G.V. (2014). Stratehichnyi kontrolinh yak pidsystema stratehichnoho upravlinnia [Strategic controlling as a subsystem of strategic management]. Businessinform. No. 4, pp. 453-459 (in Ukrainian)

Nowak E. (2011). Controlling w dzialalnosci przedsiqbiorstwa. Warszawa: Polskie Wydawnictwo Ekonomiczne.

Porohnya V.M., Losj V.O. (2008). Modelyuvannya ekonomicheskoi dodanoi vartosti na pidprismstvstvi [Modeling the economic added value at the enterprise]. Bulletin of the Zaporizhzhya National University. No. 1(3), pp. 107-114. (in Ukrainian)

Posylkina O.V., Dorovsky Yu.E., Novytska Yu.E., Chromykh A.G., Demchenko N.V. (2015). Metodychni zasady vprovadzhennia systemy kontrolinhu upravlinnia zapasamy farmatsevtychnoi produktsii $\mathrm{v}$ optovykh farmatsevtychnykh kompaniiakh [Methodical bases for implementation of the management controlling system over pharmaceutical inventory at wholesale pharmaceutical companies]. Management, economics and quality assurance in pharmacy. No. 5(43), pp. 60-67. (in Ukrainian)

Sierpiriska M., Niedbala B. (2011). Controlling operacyjny w przedsiqbiorstwie. Warszawa: Wydawnictwo Naukowe PWN. Smolinska N.V. (2011). Metodychni pidkhody do otsiniuvannia rivnia innovatsiinoi spromozhnostnosti pidpryiemstva [Methodical approaches to assessment of the enterprise's innovative ability]. Marketing and management of innovations. No. 4, Vol. I, pp. 215-221. (in Ukrainian)

Refauter D. (1990). Strategisches Controlling auf der Basis des Cash Flow. Wiesbaden.

Reta M.V. (2016). Diagnostika u sistemy strategicheskogo upravlinskogo obliku: suchasni napryamki ta pidkhodi [Diagnostics in the system of strategic management accounting: modern directions and approaches]. Problems of Economy. No. 3, pp. 192-198. (in Ukrainian)

Taran A.A. (2013). Poisk effektivnykh instrumentov upravlencheskogo ucheta dlya selskokhozyaystvennogo predpriyatiya [Searching for effective tools for management accounting for an agricultural enterprise]. Retrieved from: http://grani3.kznscience.ru/data/documents/5_Taran.pdf (accessed on 02 March 2018) (in Russian)

Smd (2017). Tendentsii farmatsevticheskogo rynka Ukrainy [Tendencies in the Ukrainian pharmaceutical market]. Retrieved from: http://smd.net.ua/files/162_ukrainemarketresults_y2017_smd_rus.pdf (accessed on 12 February 2018) (in Russian)

Weber J. (2001). Wprowadzenie do controllingu. Katowice: Oficyna Controllingu. 